\begin{tabular}{ccc} 
Contents available at: Sri Lanka Journals Online & Tropical Agricultural Research \\
Journal Home Page: https://tar.sljol.info & \\
\hline
\end{tabular}

\title{
Economy-wide Impacts of Tariff Cuts and Productivity Improvements in Agriculture: A Computable General Equilibrium (CGE) Analysis for Sri Lanka
}

\author{
C. Swarnathilake ${ }^{1 *}$, S.A. Weerasooriya ${ }^{2}$ \\ 1 Postgraduate Institute of Agriculture, University of Peradeniya, Peradeniya, 20400, Sri Lanka \\ 2 Department of Agricultural Economics and Business Management, Faculty of Agriculture, University of Peradeniya, \\ Peradeniya, 20400, Sri Lanka
}

\begin{tabular}{l}
\hline \\
ARTICLE INFO \\
\hline Article history: \\
Received: 19 August 2020 \\
Revised version received: 16 February \\
2021 \\
Accepted: 15 March 2021 \\
Available online: 1 October 2021
\end{tabular}

Keywords:

Applied general equilibrium analysis Expenditure elasticities Productivity improvements

Social accounting matrix

Tariff cuts

\begin{abstract}
Citation:
Swarnathilake, C. and Weerasooriya, S.A. (2021). Economy-wide impacts of tariff cuts and productivity improvements in agriculture: A computable general equilibrium (CGE) analysis for Sri Lanka. Tropical Agricultural Research, 32(4): 390-408.
\end{abstract}

DOI: http://doi.org/10.4038/tar.v32i4.8508

Swarnathilake, C.

https://orcid.org/0000-0002-8470-8406

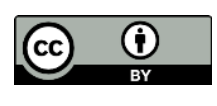

\section{ABSTRACT}

This study provides a quantitative assessment of the likely economy-wide impacts of tariff cuts and productivity improvements in agriculture for Sri Lanka. A static, multisector, Computable General Equilibrium (CGE) model, using the Supply and Use Table (SUT) of 2010, was employed highlighting specified agricultural sub-sectors and their interactions with other production sectors in the economy. Constructing a CGE model entailed the development of a Social Accounting Matrix (SAM) to represent the Sri Lankan economy. The SUT, household income and expenditure survey, economic stat of the Department of Census and Statistics, and economic data library of the Central Bank of Sri Lanka were used to develop the SAM. The SAM was used to calibrate the CGE model. Coding and operationalization of the CGE model were executed using the PATH solver of the General Algebraic Modeling System software using a modified version of the standard CGE model. Production was specified as a Constant Elasticity of Substitution (CES) production function whereas consumption was specified as a Linear Expenditure System (LES). Using the HIES data, the LES was estimated using a seemingly unrelated regression model. The CGE model included a representative household, two factors of production i.e., labor and capital, commodities, activities, the government, savings, and investment and trade. Productivity improvements in the selected agricultural subsectors lead to a significant positive response in the paddy, vegetables, coconut growing, and livestock sectors. However, productivity improvements in the specified agricultural sectors lead to a decline in demand for labor because of improved primary factor productivity and the decline of market prices. A cut in prevailing tariffs in agricultural industries shows negative impacts on households as a whole.

\footnotetext{
* Corresponding author: chanukaswarnathilake@gmail.com
} 


\section{INTRODUCTION}

The agricultural sector continues to play a very important role in the Sri Lankan economy even though its relative position in the economy has been declining with the growth of other sectors, revealing a structural change throughout economic development. The agriculture sector accounts for 25.5 percent of total employment and 21.66 percent of total exports in 2018 and contributes nearly 25 percent of the growth of export earnings. The role of the agriculture sector remains important in food security, poverty reduction, employment generation, provision of raw materials to non-agricultural sectors, foreign exchange earnings, and overall sustainable development. The low agricultural share in Gross Domestic Product (GDP) of around 7 percent presently is notable implying the low-income received by farmers. Nearly 80 percent of the population resides in rural areas where the majority of them still depend directly or indirectly on agriculture for their livelihoods. Given this, development in agriculture has been considered by successive governments as a means for poverty alleviation.

According to the Central Bank of Sri Lanka (2018), agricultural productivity growth was around 8 percent for the past few decades. The current agriculture policy in Sri Lanka is directed towards improving productivity in many sub-sectors in aligning them to be more competitive. It aims to create exportable surpluses or import substitution to strengthen the balance of payment of the country while increasing the income levels of the people who are engaged in agriculture.

Policy analysis in the context of agriculture is integral in the process of planning and implementing agricultural policies. Undoubtedly, these policies play a big role in shaping up a country's agriculture hence, there is a great need for quantitative policy analysis. Policy analysis refers to the art and science of determining which public policy, among alternatives, will most likely achieve a determined set of goals. Policy analysis aims to assist policymakers in choosing desired courses of action by illuminating the problem, outlining the alternative solutions, and displaying tradeoffs among their consequences (Walker, 2000).

Within the realm of policy analysis, Computable General Equilibrium (CGE) models which make use of general equilibrium principles have received much interest and appeal since the seminal work done by Dervis, De Melo, and Robinson (1982). It involves finding an efficient allocation of resources among agents and sectors under given resource and technology constraints. This type of approach is appropriate when the researcher seeks to capture the economy-wide consequences of policies and programs (Waters, Holland, and Weber, 1997). Using a CGE model has several distinct advantages. First, it allows one to observe the unobservable, that is, what the economy would have looked like without the policy. Second, the CGE model enables the user to trace an impact of a policy through numerous linkages to product and factor markets, along with households, institutions, and trade (Reimer, Weerasooriya, and West, 2015). Third, a CGE model is appropriate when the user seeks to capture effects in markets beyond those that are directly subject to the policy (U.S. Environmental Protection Agency, 2010). Fourth, a CGE model enables a comprehensive analysis that would consider not only direct beneficiaries and their well-being but people and businesses that are indirectly affected by a particular policy.

One major rationale for this study was that very few CGE models have been constructed and applied for Sri Lanka. Further, these models are not freely available for policy analysis within an applied general equilibrium framework. In this study, an open-access CGE model of Sri Lanka was developed which can be used by academics as well as policy analysts working in the government sector. Such a model would serve as an openaccess policy tool in which various policies (not limited to agriculture) can be analyzed. Notably, most of the agricultural policies are macroeconomic which warrants the use of general equilibrium as opposed to partial equilibrium as general equilibrium models incorporate complex interdependencies among agents and sectors in the economy (Thiessen, 1998). This study analyzes some key policy approaches in the agriculture sector in the form of productivity improvements and tariffs. It is timely and important that a CGE model is used in policy analysis in the agriculture sector with a special focus on macroeconomic policies to discern economy-wide impacts.

This study used a modified version of the standard CGE model proposed by Hosoe, Gasawa, and Hashimoto (2010) and Löfgren, Robinson, and Harris (2002). Constructing a CGE model first entailed the development of a Social Accounting Matrix (SAM). Thereafter, the SAM was used to calibrate/parameterize the CGE model which was subsequently used to analyze the economy-wide impacts of two hypothetical policy changes related to agriculture. Overall, CGE models are the primary tool for analyzing the impacts across 
multiple markets of changes in one or more policy variables. These are model parameters that are either price-based (e.g., taxes and subsidies) or quantity-based (constraints on demand or supply, etc.), and whose values are often exogenously stated by the analyst. When the economy is initially at its unregulated equilibrium, the perturbation in prices, activity levels, and demands caused by a change in the values of these parameters induce convergence to a new, distorted equilibrium. By comparing the pre-and post-change equilibrium vectors of prices, activity levels, demands, and income levels, the policy may be evaluated, subject to the limitations of the accuracy and realism of the model's assumptions (Bellù, 2011).

The objective of this study is to quantify the effects of productivity improvements and tariff cuts in selected agricultural sub-sectors in Sri Lanka on macroeconomic variables in the economy such as GDP and employment and the effects on domestic production, prices, sectoral employment, and household incomes by employing a static multi-sector, multi-household CGE model. The remainder of the paper is organized as follows. The next section describes the salient features of the SAM and the standard CGE model. The following section draws on the literature conducted on CGE studies done concerning Sri Lanka and CGE studies conducted to analyze agricultural policies in developing countries. The subsequent sections describe the methodology, data, and how the coding was carried out, and the results of the policy simulations. The final section concludes with the conclusions and implications.

\section{Salient features of the Social Accounting Matrix and the standard CGE model}

A Social Account Matrix or a SAM is a comprehensive, economy-wide data framework, typically representing the economy of a nation/region (Löfgren, Robinson, and Harris, 2002). Technically, the SAM is a square data matrix, and each cell entry corresponds to an income transfer from the account of its column to the account of its row for services rendered or goods supplied. In other words, the columns and rows correspond to a unique account, with a cell corresponding to a payment made from the account of its column to the account of its row. The sum of a column gives the total expenditure made by that particular account to all other accounts. Similarly, the sum of a row represents all income payments to that particular account by all other accounts. Adhering to the double-entry accounting principle, for each account in the SAM, the total revenue/row total equals total expenditure/column total (Löfgren, Robinson, and Harris, 2002). A few salient features of the SAM are given below.

First, the SAM distinguishes between activities and commodities. Activities are the entities that are used as inputs or intermediate goods in production and are valued at producer prices. Commodities correspond to activity output and are valued at market prices. Separation of activities and commodities is preferred as it permits activities to produce multiple commodities (e.g., poultry as an activity will result in chicken and eggs as commodities) and allows any commodity to be produced by multiple activities. Second, SAM consists of two factors i.e., labor and capital. Rows correspond to factors income whereas; columns correspond to factor expenditure. Third, the SAM can consist of a representative household (the number can be changed based on the objectives). The row corresponds to household income whereas; the column corresponds to household expenditure. Fourth, the SAM includes institutions in the form of government and investment. They too consist of rows, which correspond to income, and columns, which correspond to expenditure. Finally, SAM consists of the rest of the world. The row corresponds to foreign exchange outflow while the column corresponds to foreign exchange inflow. In general, the row and column totals add up to be the same i.e., the SAM is balanced. Since column totals are equal to the row totals, the SAM is balanced and can be used to obtain economic parameters of interest (e.g., Gross Domestic Product).

The standard CGE model incorporates optimizing households and firms, intermediate input use, inter-household, and government transfers, savings and investment, government, and trade with the rest of the world. The model combines the Walrasian general equilibrium with realistic economic data and simulates levels of supply, demand, and price that bear equilibrium across a specified set of markets. Accordingly, it is based on a set of simultaneous linear and nonlinear equations that define the behavior of economic agents as well as the market equilibrium conditions. Households receive income from labor, capital, inter-household transfers, government transfers, and investment income. Households spend money on commodities, inter-household transfers, government taxes, and investment. Households are assumed to maximize a StoneGeary utility function subject to an expenditure constraint (Reimer and Weerasooriya, 2019). The 
resulting first-order conditions are linear expenditure system (LES) demand functions. This is given in equation (1).

$D_{i h}=\lambda_{i h}+\frac{\beta_{i h}\left[I_{h}-\sum_{j} \lambda_{j h}\left(1+t c_{i}\right) p_{j}\right]}{\left(1+t c_{i}\right) p_{i}}$

where $D_{i h}$ is the final demand in the $i^{t h}$ consumption category for household type $h, \lambda_{i h}$ is the subsistence level parameter for Stone-Geary utility function for the $i^{\text {th }}$ consumption category for household type $h, \beta_{i h}$ is the marginal budget share parameter for the Stone-Geary utility function for the $i^{\text {th }}$ consumption category for household type $h, I_{h}$ is the income of household type $h, t c_{i}$ is the consumption tax paid by the households for the $i^{\text {th }}$ consumption category and $p_{i}$ is the commodity price for the $i^{\text {th }}$ consumption category. Both $i$ and $j$ are indexed for commodities and $h$ is indexed for different types of households. LES demand functions indicate how a household's optimal bundle of goods will change in response to changes in prices and their spending constraint. Production is carried out by firms (represented by activities) that are assumed to maximize profits subject to their technology, taking prices (for their output, intermediate inputs, and factors) as given. Firms engage in the production of commodities combining capital and labor, intermediate inputs based according to a Constant Elasticity of Substitution (CES) function. This is given in equation (2).

$$
Y_{a}=\frac{\theta_{a}}{1-t v a_{a}-\sum_{i} i c a_{i a}}\left(\sum_{f} \delta_{f a} * F_{f a}^{-\rho_{a}}\right)^{-\frac{1}{\rho_{a}}}
$$

where $Y_{a}$ is the final production of the $a^{\text {th }}$ activity, $\theta_{a}$ is the shift parameter for the production function for the $a^{t h}$ activity, $t v a_{a}$ is the tax on value-added for the $a^{\text {th }}$ activity, $i c a_{i a}$ is the quantity of the $i^{\text {th }}$ good used as an intermediary input per unit of the $a^{\text {th }}$ activity, $F_{f a}$ is the quantity of the $f^{\text {th }}$ factor demanded by the $a^{\text {th }}$ activity, $\delta_{f a}$ is the share parameter for the production function for the $f^{\text {th }}$ factor demanded by the $a^{\text {th }}$ activity and $\rho_{a}$ is the exponent for the production function for the $a^{\text {th }}$ activity. Both $i$ and $j$ are indexed for commodities and $f$ is indexed for labor and capital. $\rho_{a}=\frac{1}{1-\sigma_{a}}$ where $\sigma$ is the elasticity of substitution between capital, and labor. Like all standard CES functions, the above equation nests a Cobb-Douglas function when $\sigma \rightarrow$ $1 ;$ a Leontief function with fixed factor proportions when $\sigma=0$; and a linear production function with perfect factor substitution when $\sigma=$ $\infty$. Intermediate inputs are combined in fixed proportions as given in the SAM using a Leontief function. The government collects taxes and receives transfers from all other institutions. All taxes are at fixed ad valorem rates. The government uses this income to purchase commodities for its consumption and transfers them to other institutions. The goods and services (i.e., commodities in the SAM) produced by the sector are either sold domestically or exported according to a Constant Elasticity of Transformation (CET) function with an assumption of imperfect transformability between the two. Foreign demand for domestic products is infinitely elastic at given world prices. Domestic demand for commodities is governed by a CES aggregation function (also known as the Armington function) to reflect imperfect substitutability between imports and domestic output sold domestically. Domestic demand is made up of the sum of demands for household consumption, government consumption, investment, and intermediate inputs. The derived demand for imported commodities is met by an international supply that is infinitely elastic at given world prices. Some of the other important equations are given in Appendix A and B. Figure 1 shows the general flow of the CGE model which depicts the underlying linkages between different components.

Market equilibrium is attained by agents optimizing objective functions subject to macroeconomic constraints, including the external balance, savings-investment balance, government budget balance, and an aggregate supply of primary factors constraint i.e., equilibrium in factor markets and macroeconomic balances is established through several closure rules. External balance (the current account of the balance of payments which includes the trade balance) is achieved by adopting fixed foreign savings and variable exchange rates adjust to maintain the current account balance. Savings-investment balance is achieved by assuming savings are investment-driven. In this case, investment is fixed, and savings adjust endogenously. Investment-driven closure would be useful for analysis that quantifies the impact of those shocks through changes in investment on welfare (Hosoe, Gasawa, and Hashimoto, 2010). Government balance is achieved by allowing government savings to be flexible while fixing all tax rates and fixing government consumption. This set of macro closure rules mimics the Johansen closure where a combination of fixed foreign savings, fixed real investment, and fixed real government consumption is preferred for simulations that explore the equilibrium welfare changes of alternative policies (Löfgren, Robinson, and 
Harris, 2002). In factor markets, it is assumed that both capital and labor are fully employed, fixed in supply, and mobile across sectors.

\section{CGE in the context of Sri Lanka and agricultural policy analysis}

The literature review revealed that there had been few instances where CGE models had been used in a Sri Lankan context. The popularity of the CGE modeling approach in Sri Lanka can be attributed to the shortcomings of the partial equilibrium approach to macroeconomic policy transformations. The main aim of the CGE approach is to transform the Walrasian general equilibrium structure from an abstract representation of an economy into realistic models of actual economies. Given this context, a brief exposition of the CGE studies conducted in Sri Lanka and policy analysis is warranted.

One of the first instances a CGE model for Sri Lanka was constructed was by De Melo (1978). The theoretical structure of this model was based on the World Bank CGE model static structure (initiated by Adelman and Robinson, 1978 and Dervis, De Melo, and Robinson, 1982). Profit and utility maximization by consumers and producers were assumed here. CES production function was specified with substitution possibilities at each production level. Households were grouped into six categories and their incomes were determined through a factor ownership matrix. Demand for households was estimated through a spliced linear expenditure system. The role of government was introduced into the model using various taxes and constant sectoral expenditure shares (Naranpanawa, 2005). Blitzer and Eckaus (1986) developed a neo-classical CGE model for Sri Lanka with special reference to energy-economy interactions. This model focused on the impact of energy costs and prices on key macroeconomic variables and the industrial structure in Sri Lanka. The Leontief form was specified for all intermediate demand and the Cobb-Douglas production functions were used to specify the relationship between output and primary factors. Two consumer groups were identified, and their behavior was characterized by an extended LES.

A structuralized CGE model was developed for Sri Lanka to ascertain the experience of stabilization and adjustment programs in LDCs and to find an alternative to the orthodox IMF World Bank stabilization approach (Bandara, 1991). This model focused mainly on structural rigidities and was socially more appropriate than the neoclassical models. This model was demand-driven but captured structural rigidities of the supply side. The agriculture sector had a fixed supply and the manufacturing and service sectors had demand-determined output. This model was aggregated which consisted of four sectors: agriculture, processed food, industrial and manufacturing, services, trade, and transport. A flexible CGE model was developed to capture the current structure of the economy by the Centre for International Economics (1991). This model was different from previously discussed CGE models for the following features. First, it was a large model that adequately represented the present structure of the economy and was able to be shocked in numerous dimensions to produce results on many economic variables of interest to a wide range of policy issues. Second, this model used flexible solution methods that allowed access for general users and local policymakers. The model developed by Bandara (1991) was a neoclassical comparative static model that concerned the implications of various internal and external shocks. This model focused on the real side of the economy and its structure was closely associated with microeconomic theory. This model highlighted the role of relative prices and substitution possibilities in determining commodity trade flows and their effects on the economic structure and distribution of factor incomes.

The CGE model developed by Somarathna (1998) mainly concerned trade liberalization and its environmental implications concerning land degradation in the non-plantation agricultural sector. This model was an update of Bandara's (1991) CGE model. Pallegedara (2010) examined the impacts of production tax and import tariff reform policies in the Sri Lankan service sector on a general equilibrium framework. To quantify the possible impacts of service sector tax policies in Sri Lanka, he employed a static CGE model for the Sri Lankan economy. Naranpanawa and Bandara (2012) conducted a case study adopting a CGE approach as an analytical framework to explore the growth and poverty impacts of high oil prices. Gunawardena (2012) did a quantitative assessment of the likely economy-wide impacts of agricultural productivity improvements using a static multi-sector CGE model of the Sri Lankan economy with the input-output table for the year 2000. Fernando et al. (2015) developed a tourismfocused CGE model for the Sri Lankan economy. The study revealed how a tourism-focused CGE model can be used to examine the economy-wide effects of an expansion of tourism on the Sri Lankan economy by carrying out a policy simulation in a business-as-usual scenario. 
It is also noteworthy to review CGE models employed in other developing countries that have looked into policies relating to agriculture. Arndt and Tarp (2000) used a CGE model to analyze improvements in agricultural productivity and reductions in marketing costs in Mozambique. They found that growing agricultural productivity is significant for Mozambique with large potential expansions. Bautista and Thomas (1997) developed a CGE model to investigate the effects of productivity increases in Philippine agriculture. The study highlighted the effects of productivity growth in three agricultural sectors: food crops, export crops, and livestock and fishing sectors, and the food manufacturing sector on sectoral prices and outputs, rural and urban income, trade balance, and national income. The simulations indicated a 10 percent rise in total productivity distinctly in the four sectors and increased productivity in all sectors simultaneously.

Coxhead and Warr (1991) used a CGE model for the Philippines to examine the distributional effects of technical progress in the Philippine agriculture sector. They indicate, in a small open economy, technical improvements in farming are likely to detriment the poor, especially if the technical change is labor-using, land-saving. The same model used by Coxhead and Warr (1995) attempted to capture the effects of differential rates of technical progress in the irrigated and non-irrigated agricultural sectors on the income distribution of factor owning household groups, poverty, and economic welfare within a small open economy with open agricultural trade and agricultural trade under constraints. The results noticeably disclosed that reduced poverty from technical progress is substantially greater when agricultural trade is unrestricted at a constant world price. Warr and Coxhead (1993) examined the distributional effects of technical change in the Philippines' agriculture with a general equilibrium model. They demonstrate that technical change in Philippine agriculture elevated incomes, condensed poverty, and upgraded the income distribution. De Franco and Godoy (1993) built a CGE model for Bolivia to illustrate that, developments to crops generate all-around benefits in the economy, stimulating growth and employment. Nevertheless, improvements to the major non-tradable, potatoes have significant effects than improvements to traded crops like wheat or soybeans. When the price of potatoes drops, real income rises because of poor people spending a larger amount of their household budgets on food. Diao, Dorosh and Rahman (2003) used a CGE model for Uganda to quantify the linkages among agriculture, other sectors in the economy since agriculture is a leading sector in the Ugandan economy and to evaluate the implications of different external shocks. The model executed simulations to capture the effects of alterations in world coffee prices, agricultural productivity shocks, declines in agricultural marketing costs, and variations in foreign capital inflows. They concluded that broader rises in agricultural productivity and falls in marketing costs would more likely nurture rural incomes in Uganda with the largest gains in regions where home consumption is lower. De Melo (1988) surveyed the contribution of CGE models designed to quantify implications of trade policy scenarios in developing countries and bolstered the argument of the usefulness of CGE models as a tool for policy analysis. De Melo (1988) further postulated that a range of trade policy issues in developing countries can be investigated using CGE models.

\section{METHODOLOGY}

In developing the SAM, data was critical, and they are organized to encompass a tremendous array of information on households' income and expenditure, price changes, transfers of taxes and benefits, etc. In constructing the SAM, Supply and Use Table (SUT) (or the Input-Output Table) in 2010 from the Department of Census and Statistics (DCS), Sri Lanka was used to obtaining the intermediate consumption among all the sectors, gross value added, imports, exports, consumption expenditure of activities and commodities, taxes few subsidies on production and imports and compensation of employees. Economic-stat-data of the DCS was referred to obtain current transfers and salaries and wages. Economic Data Library of the Central Bank Sri Lanka (CBSL) was referred to obtain government tax revenue, changes in stocks, international investment, private savings, government savings, national savings, agriculture, industry and service GDP, factor income from abroad, household final consumption expenditure and net current transfers from the rest of the world.

Detailed information on the households' incomes and spending were collected and compiled using the Household Income and Expenditure Survey (HIES) from the DCS, Sri Lanka. Four sectors were identified and used as activities and commodities in the SAM i.e., agriculture, food manufacturing, other industries, and services. Besides, there are two factors of production i.e., capital and labor. 


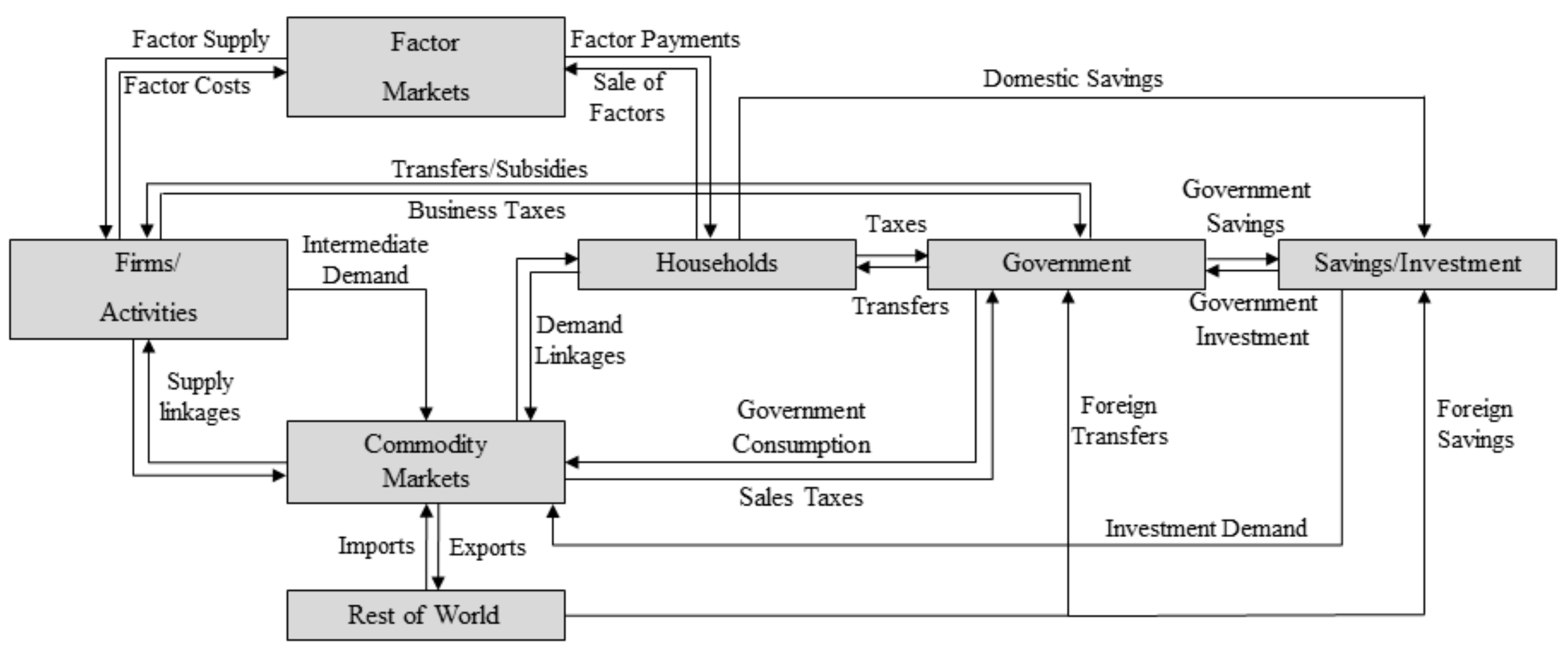

Figure 1. Schematic diagram indicating the flows in the Standard CGE model 
A single representative household was specified in the model. Construction of the SAM was done in excel and all the data sources and how each cell was calculated in the SAM were documented for future users. Once the SAM was constructed, several checks were done to ensure whether it is balanced. Once the SAM was balanced, it was used to calibrate the CGE model which is discussed in subsequent sections.

The next step entails coding and calibrating the CGE model. The balanced SAM described above represents the economy with policies already in place (or no policies if the interest is about implementing a policy). To understand how a policy, influence the economy, a counterfactual scenario in which these policies were not in place is required (alternatively if the interest is on implementing policy, this counterfactual scenario becomes a situation in which the proposed policy is implemented). Since this is not observed, it must be simulated. There are different ways to do this. One is to use an input-output model. It has the advantage of being easy to understand, having a simple specification, and contains information on a fairly large number of disaggregated sectors. On the downside, it does not allow for behavioral responses on the part of many different agents. In other words, an input-output model assumes fixed prices and technology which in return prohibit behavioral reactions by producers and consumers (U.S. Environmental Protection Agency, 2010). In contrast, this study employs a CGE model based on the path-breaking approach of Löfgren, Robinson, and Harris (2002). The model traces the impacts of a change, and it will represent a move from a base equilibrium (with the policy/without policy) to a new equilibrium (without the policy/with policy), to compare the two states. Since the model is static, it does not give a timedependent dynamic path of adjustment (Hanson and Somwaru, 2003). The use of the model in this context is valuable in two ways. First, it allows one to observe the unobservable, that is, what the economy would have looked like without the shock. Second, the model offers complete coverage in a consistent format of all the sectors that could be affected by each of the policies. While distinct, they have in common numerous linkages to product and factor markets, along with households, institutions, and trade.

The coding and operationalization of the Standard CGE model were done using the General Algebraic Modeling System (GAMS) software. GAMS software is used frequently in CGE modeling as it provides a solid base for coding. Hosoe, Gasawa, and Hashimoto (2010) and International Food
Policy Research Institute (IFPRI) coding system were used as a starting point. The CGE model comprises a set of non-linear simultaneous equations and they are solved using the PATH solver of the GAMS software. The SAM is used to calibrate most model parameters. During calibration, all prices in the model are set to unity and the base year factor levels and SAM flows are substituted into the model as equilibrium values of model variables. The model also contains several exogenous parameters that are set by the user. Some of the parameters of the standard CGE model such as expenditure elasticities and other parameters are set by the user through literature review or estimations. For example, the estimation of expenditure elasticities, the LES functional form was used, and Seemingly Unrelated Regression (SUR) was used as the econometric tool. Using equation (1), the LES demand system is given by the following equation which was obtained by maximizing a Stone-Geary utility function subject to a linear budget constraint (Reimer and Weerasooriya, 2019; Weerasooriya and Reimer, 2020):

$$
w_{i}=\gamma_{i} \frac{p_{i}}{m}+\beta_{i}\left(1-\frac{\sum_{j=1}^{l} p_{j} \gamma_{j}}{m}\right)+\sum_{r=1}^{s} \theta_{i r} Z_{r}+\mu_{i}
$$

where $w_{i}=\frac{p_{i} x_{i}}{m}$ is the budget share of the $i^{t h}$ good, $p_{i}$ is the price of the $i^{t h}$ good, $x_{i}$ is the quantity consumed of the $i^{\text {th }}$ good, $m$ is the total expenditure, $\beta_{i}$ is the marginal budget share of $i^{t h}$ good, and $\gamma_{i}$ is the subsistence level for $i^{\text {th }}$ good. $Z_{r}$ represents a vector of $r=1, \ldots, s$ demographic characteristics. $\beta_{i}, \gamma_{\mathrm{i}}$ and $\theta_{i r}$ are the unknown parameters to be estimated. Both $i$ and $j$ are indexed from $i, j=1, \ldots, l$ where $l=8$ (eight broad categories). Error terms $\mu_{i}$ are assumed to be jointly normal and independent over observations, with zero mean and a constant covariance matrix. Since the model is non-linear in these parameters, non-linear seemingly unrelated regression was used (nlsur command in STATA). The restrictions $\sum_{i=1}^{l} \beta_{i}=1$ and $\beta_{i}>0$ ensure adding up the property of demand systems. The expenditure elasticities are calculated as:

$$
\varepsilon_{i}^{L E S}=\frac{\beta_{i}}{w_{i}}
$$

where $\varepsilon_{i}^{L E S}$ is the expenditure elasticity for the $i^{t h}$ good, $w_{i}$ is the mean expenditure on the $i^{\text {th }}$ good for the representative household. In addition, to see if results are sensitive to different functional specifications, the Linear Approximate of the Almost Ideal Demand System (LA-AIDS) and Quadratic Almost Ideal Demand System (QUAIDS) were used. The Almost Ideal Demand 
System (AIDS) proposed by Deaton and Muellbauer (1980) is a consumer demand model used primarily by economists to study consumer behavior. The AIDS model confers an arbitrary first-order estimate to any demand system and has many desirable qualities of demand systems. For instance, it assures the axioms of order, combines over consumers without raising parallel linear Engel curves, is constant with budget constraints, and is simple to approximate. An advantage of the AIDS model is that the homogeneity and symmetry restrictions are straightforwardly imposed and tested. LA-AIDS was based on Green and Alston (1990) and the QU-AIDS was based on the approach proposed by Banks, Blundell, and Lewbel (1997). For the estimation of expenditure elasticities using LES, LA-AIDS, and QU-AIDS demand models, HIES data from the DCS were used.

Policy simulations related to agriculture or any sector are often subjected to the availability of data. It is common practice in CGE modeling to disaggregate the sector of interest as much as possible and aggregate the rest together. For example, for households, if the poorer households are of interest, then disaggregation is done for poor households while the non-poor households are kept aggregated. The dimensions of these data are so extensive that some of the information was not available at small time intervals; the information was only available at a point in time. Due to this reason, a base year needs to be selected. In this analysis, 2010 was chosen as it is the most recent year in which SUT is made available by the DCS. Contingent on the data availability, a different year also can be selected. The SAM as described above encompasses the economy as it was in the baseline year to which the data correspond. To gauge the impacts of a particular policy, the structure of the economy in the absence of relevant programs is required. Since it is unobserved, it is simulated using the standard CGE model. In this study, two policy scenarios related to agriculture were considered. Two policy scenarios are as follows;

\section{Simulation scenario 1:}

A set of hypothetical policy experiments were carried out to quantify the impacts of productivity improvements in selected agricultural sub-sectors on the Sri Lankan economy at the macro-level and household level. $\theta_{a c}$ (yield of commodity $c$ per unit of activity $a$ ) was the parameter shocked in this simulation scenario using the percentages depicted in Table 3.

\section{Simulation scenario 2:}

A set of hypothetical policy experiments on tariff cuts at 25, 50, and 100 percent in prevailing tariffs in agricultural industries were conducted to assess the output and employment impacts of specified agricultural sub-sectors. $t m_{c}$ (import tariff rate for commodity $c$ ) was the parameter shocked in this simulation scenario using the aforementioned percentages.

To solve the model, variables need to be defined as either exogenous or endogenous. In CGE literature, the classification of variables into exogenous and endogenous variables is identified as the closure or economic environment. The closure rules that should be selected in this setting reflect assumptions on the employed of the labor market, the rest of the world, and the policy environment. Model closure has fundamental implications for the simulation results. Therefore, the choice of exogenous variables for the model closure depends on the nature of the problem that is explored by the model user. It should be noted that the model simulations were conducted in both short-run and long-run contexts. The choice of closure depends upon the nature and availability of data, the underlying phenomena that determine them, and presumed economywide responses. For example, in short-run simulations, the real wage rate was held constant assuming the presence of institutional inflexibilities such as unions preventing a quick response to a shock. Adjustment comes via the total numbers employed, which, it was argued, is much more sensitive to short-run variations. This adhesive wage assumption can then be relieved in a long-run simulation, with real wages adjusting. Since the interest of this study was on the impact of tax rate changes, it was held exogenous and shocked by an applicable amount. However, if the government wanted to target an employment level in a particular industry, we would allow the tax rate to vary endogenously so that the exogenous employment target was satisfied (O'Toole and Matthews, 2002). In this study, simulation experiments were carried out to find the short-run and long-run effects of productivity improvements and tariff cuts on output, prices, and employment (see Appendix for more details).

In the short-run closure, on the supply side of the economy, both the physical capital stocks and the real wages were assumed to be exogenous. The physical capital stock was fixed in each industry, assuming that the industry-level output changed only through the changes in labor input. Although the capital stock is fixed, the rate of return on the capital stock within each industry was determined 
endogenously. Similarly, it was assumed that in the short-run, the economy shows a slack labor market, consequently allowing the aggregate employment as well as the employment levels of various categories of labor to be determined endogenously. Real wages on the other hand were considered to be fixed and allowed to fluctuate only in the long-run. Moreover, other primary factors such as land were fixed, and that the technical changes in the production process were also constant during the projection period. On the demand side of the economy, according to the typical short-run closure, real private consumption expenditure, real investment expenditure, real government expenditure, and real demands for inventories were set to be exogenously determined. However, the balance of trade was allowed to be determined endogenously. As highlighted by Dixon and Moon (1993) the justification for this was based on the fact that the tariff policy operated as an expenditure instrument. Furthermore, as production technologies and household consumption preferences were usually expected to change over a long period, hence were set to be exogenous in the short-run. Correspondingly, agricultural land, the number of households, the foreign prices of imports, subsidies, all tax rate variables, and the demand curves of exports were determined exogenously. Moreover, the nominal exchange rate was fixed and considered to be the numeraire. Thereby, fluctuations in domestic price indices can be read as changes in domestic prices compared to world prices. Corresponding to many other CGE simulations, the short-run solution period was assumed as 1 to 2 years.

In the long-run closure, on the supply side of the economy, both the rate of return on capital and aggregate employment were permitted to be exogenous. Therefore, the industry-level capital stock was able to fluctuate over a long period, thus letting it be determined endogenously. Hence, the producers were allowed to reposition the industry capital stock to accomplish the exogenously given rate of return on capital. Aggregate employment was set to be fixed in the long-run, assuming the economy was in full employment at the long-run equilibrium. Therefore, the real wages were set to be determined endogenously. However, labor was allowed to move between industries. On the demand side of the economy, some components of real domestic absorption were determined endogenously. For example, the real private consumption expenditure was set to be determined endogenously while allowing real government consumption expenditure to follow private consumption. So, both the overall shift term for consumption and the ratio between the overall shift term for government demand and that for consumption were exogenous. Moreover, aggregate investment was permitted to be determined by industry-specific rules. The demand for inventories, still, was set to be fixed. The balance of trade was determined exogenously. Like the short-run closure, production technologies, agricultural land, the number of households, the foreign prices of imports, subsidies, all tax rate variables, and the demand curves of exports were expected to be determined exogenously. In the policy simulations, in the short-run, factor supplies, exchange rates were fixed whereas allowed to vary in the long-run. Based on the closure rules, simulations were executed as depicted in Appendix A and B. For more details on the short-run and long-run closure rules, refer to Naranpanawa (2005).

\section{RESULTS AND DISCUSSION}

\section{SAM for Sri Lanka}

From the data obtained from a variety of official sources, the SAM was developed for Sri Lanka. As depicted in Table 1, SAM consists of activities, commodities, and factors of production, households, institutions, and the rest of the world trade. Activities are the entities that are used as inputs or intermediary goods in production. Commodities refer to the final product of the activity output. Activities and commodities are separated which allows any commodity to be produced by multiple activities and any activity to be used in producing multiple commodities. The SAM allows all 8 sectors to act as an activity as well as a commodity. In GAMS coding, suffice-A implies that this is an activity and suffice-C implies that it is a commodity. Paddy as a sector used LKR 26 billion of paddy, LKR 54 billion of agricultural, LKR 21 billion of industrial and manufactured goods, and LKR 33 billion from services. This activity also used LKR 211 billion of labor and LKR 21 billion of capital. Households as a whole sold LKR 2,104 billion of labor and LKR 480 billion of capital. They purchased LKR 5 billion of paddy, LKR 2 billion of vegetables, LKR 47 billion of livestock, LKR 12 billion of coconut, LKR 788 billion of food manufacturing goods, LKR 40 billion of industry goods, and LKR 627 billion of services. Table 1 also shows in some detail the factors of production (labor and capital) as well as institutions, government, business taxes, investment, and trade with the rest of the world. Since column totals are equal to the row totals, the SAM is balanced and can be used to obtain economic parameters of interest. 
Table 1: SAM for Sri Lanka (in LKR Billion)

\begin{tabular}{|c|c|c|c|c|c|c|c|c|c|c|c|c|c|c|c|c|c|c|c|c|c|c|c|c|c|}
\hline & \multicolumn{8}{|c|}{ Activities } & \multicolumn{8}{|c|}{ Commodities } & \multicolumn{2}{|c|}{ Factors } & \multirow{2}{*}{\begin{tabular}{|c|}
$\begin{array}{c}\text { House } \\
\text { holds }\end{array}$ \\
19 \\
\end{tabular}} & \multicolumn{5}{|c|}{ Institutions } & \multirow{2}{*}{$\begin{array}{c}\begin{array}{c}\text { Rest of } \\
\text { the world }\end{array} \\
25 \\
\end{array}$} \\
\hline & 1 & 2 & 3 & 4 & 5 & 6 & 7 & 8 & 9 & 10 & 11 & 12 & 13 & 14 & 15 & 16 & 17 & 18 & & 20 & 21 & 22 & 23 & 24 & \\
\hline \multicolumn{26}{|l|}{ Activities } \\
\hline 1. Paddy & & & & & & & & & 366 & & & & & & & & & & & & & & & & \\
\hline 2. Vegetables & & & & & & & & & & 10 & & & & & & & & & & & & & & & \\
\hline 3. Livestock & & & & & & & & & & & 422 & & & & & & & & & & & & & & \\
\hline 4. Coconut & & & & & & & & & & & & 69 & & & & & & & & & & & & & \\
\hline 5. Other agriculture & & & & & & & & & & & & & 304 & & & & & & & & & & & & \\
\hline $\begin{array}{l}\text { 6. Food } \\
\text { manufacturing }\end{array}$ & & & & & & & & & & & & & & 1197 & & & & & & & & & & & \\
\hline 7. Industry & & & & & & & & & & & & & & & 797 & & & & & & & & & & \\
\hline 8. Services & & & & & & & & & & & & & & & & 2848 & & & & & & & & & \\
\hline \multicolumn{26}{|l|}{ Commodities } \\
\hline 9. Paddy & 26 & & & & & 287 & 43 & 4 & & & & & & & & & & & 5 & & 1 & & & & \\
\hline 10. Vegetables & & 1 & 1 & & & 2 & & 1 & & & & & & & & & & & 2 & & & & & & 3 \\
\hline 11. Livestock & & & 11 & & 4 & 260 & & 10 & & & & & & & & & & & 47 & & 90 & & & & \\
\hline 12. Coconut & & & 1 & & & 34 & 11 & 1 & & & & & & & & & & & 12 & & 10 & & & & \\
\hline 13. Other agriculture & 54 & 2 & 45 & 6 & 21 & 285 & 63 & 35 & & & & & & & & & & & 47 & & 16 & & & & 38 \\
\hline $\begin{array}{l}\text { 14. Food } \\
\text { manufacturing }\end{array}$ & & & 10 & & 13 & 143 & 13 & 67 & & & & & & & & & & & 788 & & 468 & & & & 160 \\
\hline 15. Industry & 21 & 2 & 67 & 2 & 22 & 26 & 127 & 88 & & & & & & & & & & & 40 & & 56 & & & & 40 \\
\hline 16. Services & 33 & 2 & 59 & 5 & 47 & 103 & 276 & 1095 & & & & & & & & & & & 627 & & 402 & & & & 200 \\
\hline \multicolumn{26}{|l|}{ Factors } \\
\hline 17. Labor & 211 & 2 & 164 & 49 & 162 & 45 & 183 & 1288 & & & & & & & & & & & & & & & & & \\
\hline 18. Capital & 21 & 1 & 64 & 7 & 35 & 12 & 81 & 259 & & & & & & & & & & & & & & & & & \\
\hline \multicolumn{26}{|l|}{ Households } \\
\hline 19. Households & & & & & & & & & & & & & & & & & 2104 & 480 & & & & & & & \\
\hline \multicolumn{26}{|l|}{ Institutions } \\
\hline 20. Government & & & & & & & & & & & & & & & & & & & & & & 66 & 635 & 1044 & -500 \\
\hline 21. Investment & & & & & & & & & & & & & & & & & & & 950 & & -300 & & & & 93 \\
\hline 22. Income tax & & & & & & & & & & & & & & & & & & & 66 & & & & & & \\
\hline 23. VAT & & & & & & & & & & & & & 20 & 23 & 450 & 142 & & & & & & & & & \\
\hline 24. Tariff & & & & & & & & & & & & & 375 & 592 & 32 & 45 & & & & & & & & & \\
\hline \multicolumn{26}{|l|}{ Rest of the world } \\
\hline 25. Net exports & & & & & & & & & & & & & -87 & -150 & -788 & -186 & & & & 1245 & & & & & \\
\hline
\end{tabular}


Table 2: Expenditure elasticities

\begin{tabular}{lccc}
\hline \multicolumn{1}{c}{ Commodity categories } & LES & LA-AIDS & QU-AIDS \\
\hline \multirow{2}{*}{ Paddy } & 0.21 & 0.10 & 0.07 \\
& $(7.4)$ & $(1.3)$ & $1.1)$ \\
Vegetables & 0.35 & 0.17 & 0.11 \\
& $(6.1)$ & $(2.3)$ & $(2.5)$ \\
Livestock & 0.43 & 0.19 & 0.17 \\
& $(5.1)$ & $(1.5)$ & $(2.1)$ \\
Coconut growing & 0.26 & 0.12 & 0.08 \\
\multirow{3}{*}{ Other agriculture } & $(4.7)$ & $(0.8)$ & $(1.1)$ \\
& 0.35 & 0.14 & 0.10 \\
Food manufacturing & $(6.1)$ & $(1.7)$ & $1.7)$ \\
& 0.36 & 0.16 & 0.11 \\
Industry & $(5.7)$ & $(2.2)$ & $(2.4)$ \\
& 0.47 & 0.21 & 0.09 \\
Services & $(4.8)$ & $(2.4)$ & $(1.2)$ \\
& 0.87 & 0.13 & 0.13 \\
& $(8.5)$ & $(1.8)$ & $(2.2)$ \\
\hline
\end{tabular}

$\mathrm{t}$-values are in parentheses

Table 3: Targeted productivity improvements

\begin{tabular}{lc}
\hline Sub-sector & Productivity increase (percent) \\
\hline Paddy & 10 \\
Vegetables & 25 \\
Livestock & 5 \\
Coconut & 20 \\
\hline
\end{tabular}

The SAM has multiple accounts for activities, commodities, factors, and government. In each category, the GAMS codes can handle any desired disaggregation, including having just a single account. In real-world applications, the chosen disaggregation of the SAM and the CGE model depends on data accessibility and the rationale of the analysis. It is typically preferable to include relatively detailed treatment in areas of interest while keeping the database relatively aggregated in other areas (Reimer and Weerasooriya, 2019). Concerning the structure of SAM given in Table 1, several features are important. As highlighted earlier, the SAM differentiates between accounts for activities and commodities. The receipts are valued at producer prices in the activity accounts and market prices (including indirect commodity taxes and transaction costs) in the commodity accounts. This separation of activities from commodities is preferred because it permits activities to produce multiple commodities (for example, agriculture activity may produce the commodities paddy and vegetables) while any commodity may be produced by multiple activities (for example, paddy can be produced using all 8 activities). Payments are made to domestic activities, the rest of the world, and various tax accounts in the commodity columns.

In addition, the SAM also relates trade flows with transactions (trade and transportation) costs, also referred to as marketing margins. For each commodity, the SAM accounts for the costs associated with domestic, import, and export marketing. For domestic marketing of domestic output, the marketing margin represents the cost of moving the commodity from the producer to the domestic demander. It represents the cost of moving the commodity from the border (adding to the cost, insurance, and freight or the CIF price) to the domestic demander for imports, whereas, for exports, it shows the cost of moving the 
commodity from the producer to the border (reducing the price received by producers relative to the free-on-board or FOB. price). The government is disaggregated into a core government account and different tax accounts. This disaggregation is often necessary because the economic interpretation of some payments may otherwise be confusing.

\section{Econometric analysis of demand systems}

The expenditure elasticities econometrically estimated using equations (3) and (4) are given in Table 2. Besides, expenditure elasticities obtained from estimating LA-AIDS and QU-AIDS models are also given in the same table. As depicted, it can be seen that the expenditure elasticities do not vary based on different specifications in some categories. Given that the CGE model was specified using an LES, the LES expenditures were used in the CGE model as exogenous parameters.

\section{Policy simulation results}

\section{Simulation scenario 1:}

A set of simulations were carried out to quantify the impacts of productivity improvements in selected agricultural sub-sectors on the Sri Lankan economy at the macro-level and household level. These simulation scenarios were developed by taking into consideration the targeted productivity increases. Table 3 describes the targeted productivity increases. The simulation scenarios are for productivity increases in the short-run and the long-run. 10 percent productivity increase in the paddy sector, 25 percent productivity increase in the vegetables growing sector, 5 percent productivity increase in the livestock sector, and 20 percent productivity increase in coconut growing sector were carried out. These percentages are based on Mahinda Chinthana: Vision for a new Sri Lanka development framework (Ministry of Finance and Planning, 2005).

The outcomes of the productivity improvements of the specified agricultural sub-sectors as quantified in the above simulations were analyzed and interpreted as percentage change deviations from the base period. These results are given in Table 4.

The effects on macroeconomic variables such as GDP and employment and the effects on domestic production, prices, sectoral employment, and household incomes were investigated. The productivity increase led to $0.77,1.39,0.59,2.71$, $2.05,0.47,2.55$, and 1.81 percentage changes in the output of the paddy, vegetables, livestock, coconut, other agriculture, food manufacturing, industry, and services sectors in the long-run respectively. The short-run percentage changes for those sectors were $0.46,1.49,0.37,1.06,1.23$, $0.13,0.89$, and 1.76 respectively.

Table 4: Percentage changes of increased productivity on production, prices, and employment

\begin{tabular}{lcccccc}
\hline \multirow{2}{*}{ Sectors } & \multicolumn{3}{c}{ Short-run } & \multicolumn{3}{c}{ Long-run } \\
\cline { 2 - 7 } & Output & Price & Employment & Output & Price & Employment \\
\hline Paddy & 0.46 & -0.73 & -1.43 & 0.77 & -1.98 & -0.87 \\
Vegetables & 1.49 & -8.91 & -6.36 & 1.39 & -7.59 & -5.79 \\
Livestock & 0.37 & -1.51 & -1.19 & 0.59 & -0.69 & -1.04 \\
Coconut & 1.06 & -6.77 & -5.36 & 2.71 & -2.88 & -1.89 \\
Other & 1.23 & -0.45 & -0.43 & 2.05 & -0.14 & -0.20 \\
agriculture & & & & & & \\
Food & 0.13 & -0.54 & 1.32 & 0.47 & -0.62 & 0.64 \\
manufacturing & & & & & -0.42 & 1.89 \\
Industry & 0.89 & -0.81 & 1.22 & 2.55 & -0.45 & 1.31 \\
Services & 1.76 & -0.78 & 0.55 & 1.81 & & \\
\hline
\end{tabular}


When considering the labor demand, changes were recorded as $-1.43,-6.36,-1.19,-5.36,-0.43$, $1.32,1.22$, and 0.55 in the short-run and -0.87 , $5.79,-1.04,-1.89,-0.20,0.64,1.89$, and 1.31 in the long-run for paddy, vegetables, livestock, coconut, other agriculture, food manufacturing, industry, and services sectors respectively. Price changes were $-0.73,-8.91,-1.51,-6.77,-0.45,-0.54,-0.81$, 0.78 , in the short run, whereas $-1.98,-7.59,-0.69$, $2.88,-0.14,-0.62,-0.42,-0.45$, in the long-run, for the above-mentioned sectors respectively. A decline in prices was observed due to the increased supply in the market. A comparative increase of the output in non-agricultural sectors can be predicted as the usage of them as intermediate inputs in most agricultural activities. The negative labor demands were seen because of the low labor requirement due to increased productivity. However, a positive labor demand can be seen due to a comparative higher output supply in non-agricultural sectors.

\section{Simulation scenario 2:}

A set of simulations were carried out at 25,50 , and 100 percent cuts in prevailing tariffs in agricultural industries, to assess the output and employment impacts of specified agricultural subsectors. Compared to the base scenario, negative output and labor demand changes were recorded in agricultural sectors whereas positive changes were observed in non-agricultural sectors both in the short-run and long-run. When tariff cut percentage increases, the percentages of the respective increases and decreases in output and employment have become larger. As the imported price has gone down due to tariff cuts, the domestic output has decreased due to increased imports. Interestingly, the output of nonagricultural sectors has increased as it increased its use of labor (Table 5, 6, and 7).

Table 5: Percentage changes under 25 percent cut in prevailing tariffs in agricultural industries

\begin{tabular}{lcccc}
\hline \multicolumn{1}{c}{ Sectors } & \multicolumn{2}{c}{ Short-run } & \multicolumn{2}{c}{ Long-run } \\
\cline { 2 - 5 } & Output & Employment & Output & Employment \\
\hline Paddy & -0.08 & -0.43 & -0.13 & -0.52 \\
Vegetables & -0.11 & -0.77 & -0.25 & -1.03 \\
Livestock & -0.06 & -0.26 & -0.43 & -0.04 \\
Coconut & 0.13 & 0.09 & 0.10 & 0.07 \\
Other agriculture & -0.02 & -0.42 & -0.01 & -0.23 \\
Food & 1.14 & 0.45 & 2.35 & 0.51 \\
manufacturing & & & & 0.78 \\
Industry & 1.02 & 0.26 & 2.33 & 0.89 \\
Services & 1.37 & 0.56 & 2.14 & \\
\hline
\end{tabular}

Table 6: Percentage changes under 50 percent cut in prevailing tariffs in agricultural industries

\begin{tabular}{lcccc}
\hline \multicolumn{1}{c}{ Sectors } & \multicolumn{2}{c}{ Short-run } & \multicolumn{2}{c}{ Long-run } \\
\cline { 2 - 5 } & Output & Employment & Output & Employment \\
\hline Paddy & -0.10 & -0.51 & -0.16 & -0.55 \\
Vegetables & -0.15 & -0.81 & -0.29 & -1.09 \\
Livestock & -0.08 & -0.34 & -0.49 & -0.07 \\
Coconut & 0.11 & 0.05 & 0.07 & 0.06 \\
Other agriculture & -0.04 & -0.65 & -0.02 & -0.29 \\
Food & & & & \\
manufacturing & 1.10 & 0.51 & 2.30 & 0.57 \\
Industry & 0.99 & 0.28 & 2.10 & 0.80 \\
Services & 1.22 & 0.76 & 1.98 & 1.01 \\
\hline
\end{tabular}


Table 7: Percentage changes under 100 percent cut in prevailing tariffs in agricultural industries

\begin{tabular}{lcccc}
\hline \multirow{1}{*}{ Sectors } & \multicolumn{2}{c}{ Short-run } & \multicolumn{2}{c}{ Long-run } \\
\cline { 2 - 5 } & Output & Employment & Output & Employment \\
\hline Paddy & -0.13 & -0.61 & -0.22 & -0.67 \\
Vegetables & -0.19 & -0.88 & -0.36 & -1.17 \\
Livestock & -0.11 & -0.55 & -0.55 & -0.12 \\
Coconut & 0.09 & 0.08 & 0.02 & 0.04 \\
Other agriculture & -0.06 & -0.72 & -0.04 & -0.34 \\
Food & 1.07 & 0.54 & 2.23 & 0.67 \\
manufacturing & & & & 0.81 \\
Industry & 0.87 & 0.34 & 1.54 & 1.08 \\
Services & 1.10 & 0.82 & 1.76 & \\
\hline
\end{tabular}

\section{CONCLUSIONS}

In conclusion, productivity improvements in the selected agricultural sub-sectors lead to a significant positive response in the paddy, vegetables, coconut growing, and livestock sectors as well as in the other agricultural sectors, industry sector, and service sector. However, productivity improvements in the specified agricultural sectors lead to a decline in demand for labor as a result of improved primary factor productivity and the decline of market prices. Moreover, tariff cuts in agricultural industries show a negative impact on paddy, vegetables, livestock, and other agricultural sectors whereas a positive impact for the coconut sector in output and employment growth. Non-agricultural sectors showed a positive impact as a result of the tariff cuts. This impact became larger as the tariff cut percentage increased or when moving from shortrun to long-run.

Despite its appeal and relevance in policy analysis, CGE modeling approach comprises several limitations. First, the proposed CGE model is static. The results of static analysis are changes in economic activity when the economy has completed a move from a base equilibrium (with the policy) to a new equilibrium (without the policy). In reality, such changes would occur over time as the economy is incapable of adjusting instantaneously. A CGE model typically would explain and compare the before and after equilibrium but not the adjustment process over time. In other words, it does give a quantitative result, but not a time-dependent dynamic path of adjustment (Hanson and Somwaru 2003). A way forward proposed in this regard is the use of dynamic CGE models. Another disadvantage is that the CGE model does not account for heterogeneities among producers of a given commodity; the paddy industry, for example, is represented by a single sector for the nation as a whole. In contrast, it is often the case that there is heterogeneity within a sector. Another limitation is that the CGE model only provides point estimates and is estimated for a single reference year. This means that the parameter estimates may be sensitive to the choice of the reference year or based on the values set for exogenous parameters. To overcome this, a sensitivity analysis can be done. Researchers employ systematic sensitivity analysis to counter this limitation (Reimer and Weerasooriya, 2019). Another potential limitation is that full employment of productive factors is assumed, which implies that an individual's willingness to work is not affected by changes in policies or by changes in taxation. This is viewed as a conservative way of analyzing the policies because it does not allow for the possibility of net job creation. While it is important to make such an assumption to conduct welfare analysis, it is not clear that there are necessarily any biases in the results that may arise from this assumption. Readers should be aware that this is one way in which the model may depart from some of the realities of the national economy studied here.

To sum up, this study used a range of quantitative methods associated with modern economics, including econometrics, social accounting matrices, applied general equilibrium analysis, and calibration to carry out an analysis that is timely in a Sri Lankan context. While it is felt that significant progress can be made in understanding the economy-wide impacts of policy, there is room for improvement and important qualifications on 
the results. One such improvement is to conduct a systematic sensitivity analysis to identify the sensitiveness of certain parameters (similar to the work done by Reimer and Weerasooriya, 2019). Also, improvements can be made in terms of disaggregating sectors and households. This would, however, be contingent upon the availability of data. In addition, research is needed

\section{REFERENCES}

Adelman, I. and Robinson, S. (1978). Income distribution policy in developing countries: A case study of Korea (No. 10121, p. 1). The World Bank.

Arndt, C. and Tarp, F. (2000). Agricultural technology, risk, and gender: A CGE analysis of Mozambique. World Development, 28(7), 1307-1326.

Bandara, J.S. (1991). Computable general equilibrium models for development policy analysis in LDCs. Journal of Economic Surveys, 5(1), 3-69.

Banks, J., Blundell, R. and Lewbel, A. (1997). Quadratic Engel curves and consumer demand. The Review of Economics and Statistics, 79(4), 527-539.

Bautista, R.M. and Thomas, M. (1997). Income effects of alternative trade policy adjustments on Philippine rural households: A general equilibrium analysis. International Food Policy Research Institute, Washington D.C., USA.

Bellù, L.G. (2011). International price shocks and development: A general equilibrium approach with applications to Burkina Faso. Unpublished Ph.D. Thesis, Catholic University of the Sacred Heart, Milan, Italy.

Blitzer, C.R. and Eckaus, R.S. (1986). Projecting energy demand in developing countries: A general equilibrium approach. Center for Energy Policy Research, Massachusetts Institute of Technology, USA, 8-23.

Centre for International Economics. (1991). The composition and level of effective tax for exporting and import-competing production in Sri Lanka. Draft report prepared for EDB, Sri Lanka, Canberra, Australia. to revisit some of the assumptions made in carrying out policy simulations. All in all, this research sheds light on the intricacies and entwined nature of agricultural policy analysis and also provides a general equilibrium framework for future work.

Central Bank of Sri Lanka. (2018). Annual Report 2018. Retrieved from: https://www. cbsl. gov.lk/en/publications/economic-andfinancial-reports/annual-reports/annualreport-2018

Coxhead, I.A. and Warr, P.G. (1991). Poverty and welfare effects of technical change: A general equilibrium analysis for Philippine agriculture, No.332. Australian Centre for International Agricultural Research.

Coxhead, I.A. and Warr, P.G. (1995). Does technical progress in agriculture alleviate poverty? A Philippine case study. Australian Journal of Agricultural Economics, 39(1), 2554 .

De Melo, J.A. (1978). Estimating the costs of protection: A general equilibrium approach. The Quarterly Journal of Economics, 92(2), 209-226.

De Melo, J.A. (1988). Computable general equilibrium models for trade policy analysis in developing countries: A survey. Journal of Policy Modeling, 10(4), 469-503.

Deaton, A. and Muellbauer, J. (1980). An almost ideal demand system. The American Economic Review, 70(3), 312-326.

De Franco, M. and Godoy, R. (1993). Potato-led growth: The macroeconomic effects of technological innovations in Bolivian agriculture. The Journal of Development Studies, 29(3), 561-587.

Department of Census and Statistics. (2010). Input-output table. Retrieved from: http://www.statistics.gov.lk/national_accou nts/dcsna_r2/iot.php

Dervis, K., De Melo, J.A. and Robinson, S. (1982). General equilibrium models for development policy. Cambridge University Press. 
Diao, X., Dorosh, P.A. and Rahman, S.M. (2003). Market opportunities for African agriculture: An examination of demand-side constraints on agricultural growth. Development Strategy and Governance Division Discussion Paper, International Food Policy Research Institute, Washington D.C., USA.

Dixon, W.J. and Moon, B.E. (1993). Political similarity and American foreign trade patterns. Political Research Quarterly, 46(1), 5-25.

Fernando, S., Bandara, J.S., Smith, C. and Pham, T. (2015). SLCGE-tourism: A computable general equilibrium model of the Sri Lankan economy for tourism policy analysis. Griffith Business School, Discussion PapersEconomics, 6, 33.

Green, R.D. and Alston, J.M. (1990). Elasticities in AIDS models. American Journal of Agricultural Economics, 72(2), 442-445.

Gunawardena, A. (2012). Effects of increasing agricultural productivity: A computable general equilibrium analysis for Sri Lanka. Paper prepared for presentation at the $56^{\text {th }}$ conference Australian Agricultural and Resource Economics Society Annual Conference, February 7-10, Western Australia.

Hanson, K. and Somwaru, A. (2003). Distributional effects of U.S. farm commodity programs: Accounting for farm and non-farm households. Paper prepared for presentation at the American Agricultural Economics Association Annual Meeting, July 27-30, Montreal, Canada.

Hosoe, N., Gasawa, K. and Hashimoto, H. (2010). Textbook of computable general equilibrium modeling: Programming and simulations. Basingstoke UK: Palgrave Macmillan, 87-143.

Löfgren, H., Robinson, S. and Harris, R.L. (2002). A standard computable general equilibrium (CGE) model in GAMS. International Food Policy Research Institute (IFPRI). Washington D.C, USA, 5-68.

Ministry of Finance and Planning. (2005). Mahinda Chintana: Vision for a new Sri Lanka. A ten-year horizon development framework 2006-2016. Retrieved from: https://www.findevgateway.org/paper/200 5/01/mahinda-chintana-vision-new-srilanka-ten-year-horizon-developmentframework-2006

Naranpanawa, A. (2005). Trade liberalization and poverty in a computable general equilibrium (CGE) model: The Sri Lankan case. Unpublished Ph.D. Thesis. Griffith Business School, Griffith University.

Naranpanawa, A. and Bandara, J.S. (2012). Poverty and growth impacts of high oil prices: Evidence from Sri Lanka. Energy Policy, 45, 102-111.

O'Toole, R. and Matthews, A. (2002). The IMAGE CGE Model: Understanding the model structure, code and solution methods. Department of Economics, Trinity College. Dublin, Ireland.

Pallegedara, A. (2010). Impacts of service sector policy reform: CGE model analysis based on Sri Lanka. Wayamba Journal of Management, 3(2), 17-29.

Reimer, J.J., Weerasooriya, S. and West, T.T. (2015). How does the Supplemental Nutrition Assistance Program affect the United States economy? Agricultural and Resource Economics Review, 44(3), 233252.

Reimer, J.J. and Weerasooriya, S. (2019). Macroeconomic impacts of U.S. farm and nutrition programs. Journal of Agricultural and Resource Economics, 44(3), 624-645.

Somarathna, S. (1998). CGE model for trade liberalization and its environmental implications with special emphasis on land degradation in Sri Lanka, Unpublished Ph.D. Thesis, La Trobe University of Australia.

Thiessen, M. (1998). A classification of empirical CGE modeling. SOM Research Report 99C01, University of Groningen, The Netherlands.

U.S. Environmental Protection Agency. (2010). Guidelines for preparing economic analyses. National Centre for Environmental Economics. U.S Environmental Protection Agency. Washington D.C., 3-18.

Walker, W.E. (2000). Policy analysis: A systematic approach to supporting policymaking in the public sector. Journal of Multi-Criteria Decision Analysis, 9(1-3), 11-27. 
Warr, P.G. and Coxhead, I.A. (1993). The distributional impact of technical change in Philippine Agriculture: A general equilibrium analysis. Food Research Institute Studies, 22(3), 253-274.

Waters, E.C., Holland, D.W. and Weber, B.A. (1997). Economic impacts of a property tax limitation: A computable general equilibrium analysis of Oregon's measure 5. Land Economics, 73(1), 72-89.

Weerasooriya, S.A. and Reimer, J.J. (2020). Rural versus urban areas and the supplemental nutrition assistance program. Agricultural and Resource Economics Review, 49(3), 538557.

\section{Appendix A: Equations and policy simulations}

1. Demand for factor $f$ from activity $a$

$$
\tau_{f a} \cdot W_{f}=\frac{p v a_{a} \cdot \theta_{a}}{1-t v a_{a}-\sum_{i} i c a_{i a}}\left(\sum_{f f} \delta_{f f a} \cdot F_{f f a}^{-\rho_{a}}\right)^{-\frac{1}{\rho_{a}}-1} \cdot \delta_{f a} \cdot F_{f a}^{-\rho_{a}-1}
$$

where $\tau_{f a}$ is the wage distortion factor, $W_{f}$ is the average wage or rental rate for the $f^{\text {th }}$ factor, and $p v a_{a}$ is the value-added price for the $a^{\text {th }}$ activity. Both $i$ and $a$ are indexed for commodities/activities and $f$ and $f f$ are indexed as labor and capital.

2. Market equilibrium condition for factor $f$

$$
\sum_{a \in A} Q F_{f a}=Q F S_{f}
$$

where $Q F_{f a}$ is the quantity demanded of factor $f$ from activity $a$, and $Q F S_{f}$ is the quantity supplied of factor $f$.

3. Composite supply (Armington) function for commodity $c$

$$
Q Q_{c}=\alpha_{c}^{q} \cdot\left[\delta_{c}^{q} \cdot Q M_{c}^{-\rho_{c}^{q}}+\left(1-\delta_{c}^{q}\right) \cdot Q D_{c}^{-\rho_{c}^{q}}\right]^{-\frac{1}{\rho_{c}^{q}}}
$$

where $Q Q_{c}$ is the quantity of goods supplied to the domestic market for commodity $c, \alpha_{c}^{q}$ is the Armington function shift parameter for commodity $c, \delta_{c}^{q}$ is the Armington function share parameter for commodity $c$, $Q M_{c}$ is the quantity of imports of commodity $c, \rho_{c}^{q}$ is the Armington function exponent for commodity $c$, and $Q D_{c}$ is the quantity sold domestically of domestic output $c$.

4. Composite commodity markets

$$
Q Q_{c}=\sum_{a \in A} Q I N T_{c a}+\sum_{h \in H} Q H_{c h}+Q G_{c}+Q I N V_{c}+q d s t_{c}+Q T_{c}
$$

where $Q Q_{c}$ is given by the summation of $\sum_{a \in A} Q I N T_{c a}$ which is the sum of quantity of commodity $c$ as an intermediate input to activity $a, \sum_{h \in H} Q H_{c h}$ which is the sum of quantity of consumption of marketed commodity $c$ for household $h, Q G_{c}$ which is the government consumption of commodity c, $Q I N V_{c}$ which is the quantity of fixed investment demand for commodity $c$, $q d s t_{c}$ which is the quantity of stock change, and $Q T_{c}$ which is the quantity of commodity demanded as transactions service input. 
5. Commodity production and allocation (where the productivity shock was done via $\theta_{a c}$ )

$\theta_{a c} \cdot Y_{a}=Q X A C_{a c}+\sum_{h \in H} Q H A_{a c h}$

where $Q X A C_{a c}$ is the marketed output quantity of commodity $c$ from activity a, and $\sum_{h \in H} Q H A_{a c h}$ is the sum of quantity of household home consumption of commodity $c$ from activity $a$ for household $h$. A productivity increase of 20 percent can be done using the equation $\theta_{a c}=1.2 * \theta_{a c}$

6. Import prices (where the tariff shock was done via $t m_{c}$ )

$$
P M_{c}=p w c_{c} \cdot\left(1+t m_{c}\right) \cdot E X R+\sum_{c^{\prime} \in C} P W_{c^{\prime}} i c m_{c^{\prime} c}
$$

where $P M_{c}$ is the import price including transaction costs in local currency units, $p w c_{c}$ is the CIF import price in foreign currency units, $E X R$ is the exchange rate, $P W_{c^{\prime}}$ is the composite commodity price, and $i_{c m} c_{c^{\prime} c}$ is the quantity of commodity $c^{\prime}$ used as trade input per imported unit of $c$. A tariff cut of 25 percent can be done by using the equation $t m_{c}=0.75 * t m_{c}$

7. $\quad$ Export prices

$$
P E_{c}=p w e_{c} \cdot\left(1+t e_{c}\right) \cdot E X R-\sum_{c^{\prime} \in C} P W_{c^{\prime}}{ }^{\prime} i e_{c^{\prime} c}
$$

where $P E_{c}$ is the export price in local currency units, $p w e_{c}$ is the FOB export price in foreign currency units, $t e_{c}$ is the export tax rate, and ice $e_{c^{\prime} c}$ is the quantity of commodity $c^{\prime}$ used as trade input per exported unit of $c$.

\section{Appendix B: Short-run and long-run model closures}

(1) UNEMPL: Unemployment closure

If $U N E M P L=1$ : Factor supplies were fixed, factor prices vary

If $U N E M P L=2$ : The wage was fixed, labor supply varies

If $U N E M P L=1:$ Short-run

If $U N E M P L=2$ : Long-run

(2) ROWCLOS: Rest-of- the world closure

If ROWCLOS $=1$ : The exchange rate was fixed

If ROWCLOS $=2$ : The exchange rate was flexible

If $R O W C L O S=1:$ Short-run

If $R O W C L O S=2$ : Long-run 